\title{
A idade do santo. Crianças e autoridade ritual no candomblé
}

The age of the saint. Children and ritual authority in Candomblé

\author{
Christiane Rocha Falcão' \\ https://orcid.org/0000-0001-6941-789X \\ chfalcao@gmail.com \\ I Universidade Federal da Bahia - Salvador, BA, Brasil \\ Doutoranda em Comunicação e Cultura Contemporâneas
}




\title{
Resumo
}

O candomblé é uma tradição de matriz africana com organização social, hierarquia e regras próprias. Pesquisando com crianças no terreiro de candomblé ketu Ilê Axé Omin Mafé em Sergipe pode-se compreender que o mundo do candomblé possui suas próprias teorias e noções cuja relação com as teorias e noções ocidentais é de complementaridade. Durante 15 anos de pesquisa sobre candomblé ketu, tenho coletado dados sobre a experiência de crianças na religião, os lugares sociais e rituais que ocupam. Olhando para as crianças com autoridade ritual no Ilê Axé Omin Mafé fica evidente a relativização da noção (social e biológica) de criança.

Palavras-chave: candomblé; crianças; ogãs; autoridade ritual.

\begin{abstract}
Candomblé is an African tradition with its own social organization, hierarchy, and rules. Researching with children in the Candomblé ketu Ilê Axé Omin Mafé terreiro in Sergipe, one can understand that the world of Candomble has its own theories and notions whose relationship with Western theories and notions is complementary. During 15 years of research on ketu Candomblé, I have collected data on the experience of children in religion, the social and ritual places they occupy, and the experience of children who have relative ritual authority over adults and children, such as "ogian boys". Looking at children with ritual authority at Ilê Axé Omin Mafé, the relativization of the child's (social and biological) notion is evident.
\end{abstract}

Keywords: Candomblé; children; ogans; ritual authority. 


\section{Introdução}

"Esse menino é muito burro! Ele não consegue ver que aquela não é sua mãe lá? Isso é Oxalá! Sai daí, rapaz. Não seja estúpido!" O menino, 5 anos, diferente de Carol, 10 anos, não mora perto do terreiro, por isso não poderia ter entendimento do que ocorria. Ele ouviu o que Carol disse, mas continuou a chorar, chamando a mãe, puxando o vestido branco do corpo que naquele momento estava materializando Oxaguiã. Possivelmente foi a primeira vez que ele esteve no templo com sua mãe. Para Carol, essa pessoa não era a mãe do menino; obviamente era Oxaguiã. Para o menino, aquele corpo é sua mãe, então as reprovações de Carol não fariam sentido para ele de forma alguma. A materialidade da pessoa, o corpo, é o aspecto preeminente dado como certo pelos outros, e é um aspecto da relação mãe e filho que o adepto tem com seus filhos; mas essa materialidade é um veículo para aqueles outros que "operam" esse material também. Para Carol o fenômeno da possessão é óbvio porque, como uma menina de 10 anos que há muito participa dos rituais do candomblé, ela teve tempo suficiente para chegar aos fundamentos do entendimento adulto; mas para o garotinho, que teve contato com a possessão nesse episódio, o "fato material" que é o corpo de sua mãe não pode ser outra coisa senão sua mãe.

Carol vê o corpo da mulher naquele momento como Oxalá, e não como a mãe do menino. Carol experimenta a possessão através do corpo da mulher possuída por Oxaguiã, percebendo o fenômeno como naturalizado e até mesmo óbvio. O fenômeno é percebido, ou até mesmo não é percebido, de maneira diferente pelo filho da mulher, cujo habitus não é o mesmo daquela comunidade. Aqui nós temos a consciência perceptiva juntamente com a prática coletiva de que Carol faz parte dando sentido à possessão de Oxalá na mulher. Além disso, podemos ver que essa é a maneira de estar no mundo do espírito, Oxalá, que nesse momento possui agência, enquanto a mulher não está no mundo e está em um estado de passividade. No entanto, essa passividade habilitada numa linha do tempo indeterminado, uma das dimensões do possível (Rabelo, 2008, p. 96) da agência.

As crianças no terreiro vivem ao redor de orixás e de outros espíritos, e sabem disso. Ainda bebês, veem, tocam e conversam com os orixás "materializados", seja no corpo de seus familiares, seja em seus sonhos. Os orixás 
e espíritos cuidam das crianças. Eles podem ensinar e ser rudes com elas por meio de sonhos ou usando uma pessoa possuída. É por meio dessa relação que as crianças iniciam o processo de dar sentido à possessão de espíritos, 0 que é reforçado pelas brincadeiras que performam rituais e aspectos dos ritos. As diferenças entre um espírito e uma pessoa no candomblé existem tanto quanto suas semelhanças. Ambos visam um ponto comum: estar no mundo.

Num universo onde a senioridade é regra fundamental, as crianças podem ocupar um espaço não absolutamente compatível com seu status social, na perspectiva ocidental, cuja ideia geral gira em torno da figura "pura", "inocente" e dependente dos adultos. Em Santos e daimones, Rita Laura Segato (2005) argumenta acerca da necessidade de distinção entre os papéis sociais e papéis rituais nas tradições de matriz africana, caminho teórico escolhido neste artigo para discutir algumas evidências a respeito da posição de autoridade ritual que pode ser exercida por crianças no candomblé. No sentido de iluminar a relação de alteridade em que pode tomar parte a criança na tradição, neste artigo será discutido o lugar ritual do ogã-criança, segundo a teoria nativa, no sentido de argumentar que o lugar social da criança não é necessariamente o lugar social de alguém com pouca idade, mas que essas duas noções são complementares e negociadas. Essa discussão lança luz acerca da capacidade negociadora do candomblé como um sistema regido por regras e teoria próprias, mas que se reproduz materialmente e imaterialmente em diálogo com regras e parâmetros da sociedade nacional. Além disso, este trabalho visa contribuir para atualizações dos estudos que se referem às relações de poder dentro das casas tradicionais de matriz africana, através do recorte acerca da condição de autoridade ritual de algumas das crianças e de como as crianças experimentam essa autoridade.

O terreiro pesquisado, Ilê Axé Omin Mafé, situa-se no interior do estado de Sergipe e tem como uma de seus principais aspectos um forte entrelaçamento entre a família de santo e a família biológica da liderança da casa. A pesquisa foi realizada na ocasião da produção da dissertação de mestrado intitulada Ele já nasceu feito! O lugar da criança no Candomblé(Falcão, 2010), e teve como foco a experiência e perspectiva das crianças acerca da religião, se utilizando de ferramentas clássicas da antropologia, como a observação participante e entrevistas, bem como de fotografia, produção de desenhos e contação de sonhos. Também os adolescentes e adultos participaram amplamente da pesquisa. 
No início da pesquisa tive que ficar muito tempo com as crianças. Isso porque, como neófita, não podia ver alguns procedimentos sagrados que fazem parte do regime de segredos do candomblé. As crianças também não podiam ver esses procedimentos e eu me tornei a adulta responsável por cuidar delas. Enquanto os adultos estavam no espaço sagrado chamado quarto de santo, as crianças e eu estávamos no espaço público ou barracão. As crianças tiveram a ideia de me mostrar o que aconteceria dentro do quarto de santo, pois aprenderam muitos aspectos da religião observando-a desde bebês. Elas me disseram que haviam adquirido muitos conhecimentos sobre o candomblé, às vezes se escondendo da vista dos adultos durante as cerimônias, e às vezes assistindo com permissão. Três dos meninos pegaram cadeiras e começaram a tocá-las como tambores e a cantar as canções de cada orixá. Os outros meninos e as meninas formaram uma roda, e começaram a dançar as canções de cada orixá com a performance de dança utilizada pela comunidade durante as cerimônias, no xirê. Estavam me ensinando: “Chris, Ogum dança assim”, enquanto mostravam os movimentos do corpo atribuídos a Ogum. Às vezes, eles discordavam um do outro. Nino, de 13 anos, estava comigo só assistindo às meninas dançarem, e enquanto as meninas dançavam a música de Iemanjá, ele disse: "A mão não é assim! É assim [realizando o movimento], como as ondas do mar. Iemanjá me contou em meus sonhos." Todas essas informações foram uma grande iniciação para mim. As crianças também imitam alguns adeptos específicos durante suas posses e se divertem muito fazendo isso: "Olha! A Iansã do Adriano faz assim!" No entanto, essa certamente não foi a única situação em que eles "brincaram" de rituais de candomblé.

\section{“Ele não tem pra onde correr" - o destino de Júnior}

Júnior, 11 anos à época, foi desde minha inserção uma inspiração para a pesquisa. Uma das mais marcantes imagens do início da pesquisa foi a de uma mulher de aparentes 40 anos de idade biológica possuída por seu orixá, ajoelhando-se para pedir a bênção de Júnior, pequeno e franzino, em pé, vestido de branco, pairando em seu semblante uma expressão de concentração e ao mesmo tempo de naturalidade. Esse semblante sério, poderia dizer, é o mais comum de se achar em Júnior, mas a euforia nas brincadeiras e o 
sorriso fácil também seriam aspectos importantes de se citar. Bom jogador de futebol, esteve prestes a entrar para a equipe mirim do time Sergipe, na capital, Aracaju. Por dificuldade de locomoção, acabou desistindo do feito. Suas maiores companhias eram seus primos, Luis, 12 anos, e Felipe, 11 anos, embora essa turma também tenha espaço em brincadeiras com as meninas Carol, 10 anos, e Yasmin, 10 anos. Juntos costumam assistir a filmes ou programas de televisão, conversar sobre os mais variados assuntos, entre eles fofocas sobre os filhos de santo de sua avó. Em verdade, as crianças se tornaram a maior fonte de informações, por vezes capciosas, sobre os membros do terreiro. Por serem crianças, muitos membros do terreiro as julgam inocentes demais para reproduzir ou guardar algumas informações. Ledo engano. Mas um aspecto dessa turma que mais me chamou atenção desde minha inserção foram as brincadeiras simulando o candomblé. Geralmente as meninas se põem a dançar e a cantar os pontos em uma roda e os meninos se arranjam com cadeiras ou latas como seus respectivos tambores. Vez por outra um dos meninos tenta consertar a dança ou uma parte da música que as meninas estão dançando ou as meninas lembram a melodia de uma música que os meninos esqueceram. Tímido com visitas, Júnior é muito amoroso com a família, principalmente com a mãe, Cristina, com o pai, Paulo César e com a avó, Mãe Bequinha, dirigente do Ilê Axé Omin Mafé. Tem ainda um carinho forte com as crianças pequenas, como sua irmã Dandara, 3 anos, e a prima Beatriz, 1 ano. Sempre que pode tê-las nos braços e distraí-las ele o faz. Os adultos da família sempre solicitam que os meninos mais velhos façam alguns favores, como comprar algum ingrediente para o almoço ou levar um recado. Mesmo diante de algumas reclamações eles acabam obedecendo. Da mesma forma ocorre com os atributos do candomblé. Mãe Bequinha solicita dos netos que a ajudem algumas vezes na ocasião de rituais de limpeza ou iniciação. Quando a pessoa a receber o ritual é conhecida da família, eles geralmente competem para ver quem vai ajudar. Também às vezes se recusam, mas sob as ordens da avó obedecem mesmo a contragosto.

Além de ser ogã, noção a ser explorada mais a diante, do terreiro de sua mãe biológica, Júnior é um abiaxé. Um abiaxé é aquele que recebeu ainda na barriga da mãe os sacrifícios de uma iniciação ou obrigação. Por conta disso, o abiaxé não precisa se iniciar no candomblé; ele já nasce feito. Nos depoimentos de 
Mãe Bequinha, Cristina, Mércia e de outros, Júnior é um orgulho para a família. Seu comportamento "patriarcal", quase austero, quando das cerimônias é evidente e os orixás se curvam a pedir a bênção de Júnior. Os primos Wilber e Alisson, 17 e 16 anos respectivamente, ainda negociam de certa forma sua participação no candomblé, não exercendo na prática suas posições de ogã. A Júnior não é concedida tal negociação, e segundo todos da família "Júnior não tem para onde correr”. Mãe Bequinha afirma que Júnior nasceu com uma missão, com o destino traçado. $O$ único a contradizer em parte esse pensamento é seu pai, Paulo César. Paulo acredita que os filhos têm o direito de escolher se devem permanecer na tradição somente aos 18 anos de idade, quando eles terão também uma noção mais clara do que significam as responsabilidades. Ele justifica que enquanto adolescentes essa decisão é difícil, pois nesse momento as descobertas da idade concorrem diretamente com a devoção, e conforme ele diz: "Orixá é coisa séria. Se não cuidar direto [do orixá] a pessoa tá ruim, viu? E eu num quero filho meu sofrendo na mão de orixá". Já Mãe Bequinha afirma que ainda não confirmou Júnior como ogã porque o procedimento concernente com um abiaxé ogã é mais complicado e se mal realizado pode custar a vida do ogã e da sacerdotisa.

$\mathrm{Na}$ entrevista que realizamos, Júnior declarou que se sente muito orgulhoso de seu orixá, de sua condição de ogã e abiaxé. Ele me disse que costuma sonhar com um homem bem velho, curvado e se apoiando num cajado: Oxalufã, seu orixá de cabeça. Eu lhe perguntei como ele percebe seu orixá, e ele me respondeu que sente arrepios e saltos no ritmo do coração, e então sabe que o orixá está por perto. No fim da entrevista, pedi que ele falasse algo sobre o candomblé que ele quisesse que outras pessoas soubessem. Ele me disse que gostaria que outras pessoas conhecessem melhor a tradição e vissem que não é nada de ruim, mas sim muito bonita. Ele diz não se importar com algumas piadas feitas por colegas e professores na escola com relação ao candomblé, "porque essas pessoas não conhecem de verdade a religião e falam coisas que não sabem".

Maristela Guedes (2005) escreveu sobre a intolerância e a invisibilidade na escola relativa às crianças que estão no candomblé. Como jornalista, algum tempo antes da pesquisa de seu doutorado, ela fez uma reportagem sobre crianças no candomblé no Rio de Janeiro. Suas fotos foram usadas por um pastor da igreja neopentecostal Igreja Universal do Reino de Deus em um 
livro que demoniza os cultos afro-brasileiros: Orixás, caboclos e guias, anjos ou demônios? (1996). O livro foi proibido no Brasil, mas a igreja ainda continua a distribuí-lo. Na tese de doutorado, Guedes apresenta as consequências da reportagem, como a discriminação que algumas crianças estavam sofrendo na escola.

\section{Noção de pessoa do ogã-criança: destino e condição}

O destino é utilizado por alguns candomblecistas para explicarem o "eu" do ogã. Cristina Guimarães e Mãe Bequinha afirmam que o ogã vem ao mundo com alguns aspectos do destino já traçados. De alguma maneira, todos nascem com o destino traçado se uns nascem rodantes, que "rodam no santo" ou "viram no santo", e outros, não. Rita Laura Segato (2005, p. 80) distingue "personalidade", que tem a ver diretamente com o santo da pessoa, do "destino", odum. O odum é uma condição imutável imposta sobre a pessoa. Ele se relaciona com a sorte da pessoa e é consultado através dos búzios. As quedas dos búzios também possuem o nome de odum. Segundo a autora, cada pessoa nasce com o santo e o odum, e consultando os búzios elas conhecem seu santo pessoal (ou santos) e o seu odum, a fim de que dali por diante a pessoa realize os processos necessários para fixar seu real eu, que está em desequilíbrio e assim continuará se não forem feitos os procedimentos de iniciação até a "maioridade" do santo. De acordo com Rita Laura Segato (2005, p. 81):

Com relação ao odum no sentido particular de sina ou tipo de sorte que influencia toda a vida da pessoa, pode-se dizer que é entendido basicamente como o tipo de resposta recorrente que as atitudes e decisões do sujeito em questão despertam nos outros e o tipo de circunstâncias que tais ações, tipicamente, detonam. O conceito de odum, nesse sentido, é em geral menos usado do que o de santo. Ele aponta para um aspecto da vida que não pode ser controlado pela pessoa, e incorpora um fator arbitrário e aleatório que se contrapõe à racionalidade do santo como um modelo que encoraja a identificação responsável, sistemática, da parte do filho. Enquanto a personalidade, qualquer que seja seu tipo, pode ser fortalecida - os talentos que dela derivam maximizados e seus aspectos negativos, uma vez conhecidos, atenuados -, o odum é um predicado imutável. 
Segato (2005, p. 82) aponta o odum como componente da identidade pessoal que emana do orixá que é identificado pelo oráculo, porém é imune à agência humana e uma condição que "deve ser aceita e suportada". Sua autoridade já nasce com ele, está impresso em seu odum. Para Mércia, ekedi: "Somos autoridades porque Deus não nos deu o dom de nos manifestar. Temos nosso orixá, mas ele não roda na gente." Assim, compreendemos que não poder ser possuído é uma condição que nasce com o indivíduo, cujo ritual de confirmação seria o real momento de se assumir o lugar de autoridade que vem atrelada às responsabilidades da posição.

Nesse sentido, podemos afirmar que o ogã quando nasce possui, como os rodantes, seu orixá e seu destino, que é o de não receber seu orixá e de exercer uma função de autoridade. O seu destino é utilizado como definição da sua condição que é imutável e não pode ser modificada através de rituais. Compreendo então que o espaço do ogã é visto como uma condição privilegiada, mas natural, e a autoridade ritual como prática é experimentada no cotidiano, na personalização das relações com os espíritos e como experiência pública. Se o orixá age como regulador da vida pessoal do filho de santo, também é regido pelos mais velhos no santo e pelos ogãs e ekedis.

Se ogãs e ekedis podem chamar os orixás de qualquer adepto, mas ninguém nunca poderá chamar seus orixás para discipliná-los, quem os disciplina? Mércia e Paulo César afirmam que mesmo sem serem possuídos, os seus orixás têm grande autoridade sobre eles. Quando ocorre algum deslize da ekedi ou do ogã seus respectivos orixás cuidam de deixar acontecer algum problema amoroso ou no trabalho, a fim de puni-los pela desobediência. Para entender como essa determinação pelo destino molda a vida de Júnior, utilizaremos a noção de pessoa do ogã que perpassa, de acordo com Márcio Goldman (1985), pelo fenômeno da possessão, central dentro da estrutura ritual do candomblé.

Em A possessão e a construção ritual da pessoa no Candomblé, Márcio Goldman (1984) afirma que a noção de pessoa tem centralidade na discussão sobre a possessão como ritual. Para Goldman (1985), o transe molda o indivíduo. Isso se

1 Como autoridade não rodante também está a ekedi, cargo geralmente ocupado por mulheres e são quase sempre apresentadas como camareiras do santo. Existe pouca literatura sobre as ekedis também. 
deve pelo fato de que cada pessoa na Terra (aiê) é composta por uma entidade, ou várias, correspondente no plano do sagrado. Para ilustrar melhor: quando se diz que alguém é filho de Iemanjá, é porque Iemanjá se comporta como um tipo ou um pedaço de "personalidade" sagrada vinculada àquela pessoa, um doble (Luz, 2000). No momento da possessão, quando Iemanjá possui a pessoa, ali haveria um indivíduo mais completo, o sagrado e o terreno num verdadeiro "eu". Os múltiplos "eus" (Prandi, 1996) estariam naquele momento unidos, apresentando quem realmente seria aquela pessoa. A sua natureza mais real, mais profunda.

O modelo explicativo de Goldman (1984, p. 184) afirma que a noção de pessoa é construída durante o processo de assentamento dos orixás, nas obrigações que levam o adepto aos 21 anos de santo, para se tornar ebômim:

[...] a lenta construção da pessoa neste sistema religioso é efetuada em função de um complexo conjunto de rituais que se sucedem ao longo de um amplo período de tempo. Cada um desses rituais, conforme foi observado, tem por objetivo "fixar" um Orixá - que também é um componente de sua "pessoa" - na cabeça do filho-de-santo, e, além disso, e este ponto é essencial, dar-lhe o direito e o dever de ser por ele possuído. Após vinte e um anos de obrigações, e com o sétimo santo assentado, atinge-se um estado onde acontece uma possível liberação dos constrangimentos do transe; atinge-se igualmente a valorizada e desejada situação de tudo controlar, tornando-se "senhor de si" (e de outros, poderíamos acrescentar).

Dessa forma, haveria a busca pela unificação desses "eus" folheados, os quais comporiam a pessoa de cada adepto. Cada possessão seria uma tentativa da composição real de cada eu, caindo sempre em fracasso com a finalização da possessão, e dividindo sempre a existência entre o orun, o sagrado, e o aiê, o terreno. Para Goldman (1985, p. 190): “A possessão nada mais é [...] do que o oferecimento, por um fugaz instante, desta realização do Ser, e sem ela o próprio sistema (o Candomblé) deixaria de operar."

Segundo alguns religiosos, a vinda do orixá à terra se dá através do sacrifício dos animais, que tem no momento do sangue e do alimento ofertado o elo entre o terreno e o sagrado (Goldman, 1985). Dentre as habilitações de um ogã com cargo num terreiro está a sacralização dos animais de forma ritualística, o 
toque dos atabaques, a entoada dos cantos, dentre outras (Braga, 2005). Essas atividades devem ser geralmente conduzidas por pessoas que não entram em transe: ogãs e ekedis. Algumas atividades que se remetam ao manejo do sangue, ou de objetos rituais "batizados" por este, são exclusivas dos ogãs, como, por exemplo, tocar os tambores de couro. Isso se explica por conta de que os tambores quando inaugurados são banhados com o sangue dos sacrifícios, e não poderiam receber outro sacrifício, já que o sangue menstrual das mulheres é visto como tal. Alguns diferem dessa ideia, afirmando simplesmente que o sangue menstrual é impuro e que por isso a mulher não deve tocar o atabaque, instrumento que chama os orixás para possuírem seus cavalos. Ainda passando brevemente pelos gêneros no terreiro, com referência à masculinidade, haveria um entendimento por parte de alguns terreiros que somente pessoas do sexo masculino e heterossexuais podem ser ogãs, relegando-se para os homossexuais os adés (Birman, 1995), as mesmas vias de iniciação e vinculação ao terreiro que para as mulheres. Luis Felipe Rios (2004) discorda de tal colocação, afirmando que haveria casos de ogãs homossexuais, e de rodantes do sexo masculino heterossexuais.

O modelo de Goldman (1984, p. 173) compreende a pessoa no candomblé enquanto uma "síntese complexa, resultante da coexistência de uma série de componentes materiais e imateriais - o corpo (ara), o Ori [cabeça], os Orixás [espíritos], o Erê [entidades infantis], o Egum [a alma], o Exu [espírito]". Ele afirma que, mesmo nascendo com esses elementos, a integridade da pessoa está em um estado quase "virtual", e apenas com os rituais de iniciação e obrigações anuais pode corrigi-los. O "eu folheado" nasceu (biologicamente) com todos os componentes, mas ele/ela não tem estabilidade, não há equilíbrio, e com o processo de iniciação, o novo nascimento, isso pode ser reparado. Até lá, a pessoa está em um processo de construção, o que significa que todos os componentes estão sendo corrigidos. Essa é a razão da centralidade da possessão. Ela estrutura a formação do eu do adepto.

Como seria então a construção do eu do ogãa Se o ogã tem a condição de não ser possuído, e a possessão é elemento central na formação dos rodantes, como se forma o ogã ? Se a chegada aos 21 anos de santo para o rodante é a chegada ao equilíbrio, quando não há mais submissão ao orixá, o não rodante nasce equilibrado? Para algumas lideranças do terreiro, como Regiane e Ana Mércia, os não rodantes, já nasceriam como ebômims, palavra de origem 
ioruba, ou vodunce, palavra de origem fon, título dado em alguns terreiros àqueles adeptos que teriam sete ou mais anos de iniciados na religião, sendo "velhos no santo". Nessa etapa da iniciação, o adepto tem mais controle sobre a possessão, virando no santo em oportunidades raras e em sua maioria escolhidas pelo adepto (Goldman, 1984).

No modelo do Omin Mafé, o ogã já nasce quase completo, a fim de que seja "os olhos dos orixás", parte integrante do grande ciclo que é a eterna busca pela conexão entre o orun e o aiê. É sua condição de equilíbrio, de não ser possuído, que torna possível essa conexão e é o que lhe concede o poder e autoridade reconhecidos por toda a comunidade do terreiro quando confirmados, ou seja, realmente iniciados na religião. Segundo Regiane, o ogã "nunca vai ser soldado raso. Ele já nasce general", ou seja, em sua iniciação não há estágios de desenvolvimento, há somente a consagração de sua condição. Já para Mércia, é uma autoridade relativa que a ekedi e o ogã tem no orixá, porque é ele quem zela, quem corta (sacrifica) para que o orixá coma, é quem toca para que o orixá venha, mas enquanto essa autoridade não é consagrada ela não é oficial. Enquanto o não rodante não se confirma, ele é apenas uma autoridade "de boca", pois só com o processo da confirmação essa autoridade é legitimada, elemento que será enfatizado mais adiante.

Em nenhum momento percebi que essa descrição de ogã não se aplicava ou se aplicava parcialmente a Júnior, por exemplo. Em uma cerimônia no quarto de santo, Júnior se colocou na posição de receber a bênção das iaôs junto com Mãe Bequinha, Paulo César, Ana Mércia e Cristina, que são autoridades maiores no terreiro. Luis, seu primo, disse brincando: "O que você faz aí, Júnior?", questionando a autoridade do ogã. Cristina imediatamente respondeu por Júnior: “Ele está no lugar dele!” O lugar de uma autoridade; de alguém que nasceu para ocupar aquele lugar. A partir então eu percebi que quando Júnior está presente nas cerimônias até os orixás se aproximam dele para solicitar sua bênção. A autoridade de Júnior é reconhecida até pelos espíritos.

Num outro momento, eu estava no pátio do terreiro, que tem uma via de acesso direta ao quarto de santo, quando Jean reuniu sua irmã Regiane, sua filha Larissa e Júnior, seu sobrinho. Jean solicitou a Júnior que chamasse o erê de Regiane a fim de que ela e a filha pudessem pedir-lhe um favor. Júnior relutou um pouco, afirmando que talvez Mãe Bequinha não gostasse da ideia, 
mas depois de alguma insistência ele fez o que a tia pedia e chamou o erê de Regiane. Regiane é a iaquequerê do terreiro, possui mais de 20 anos de iniciação; Jean possui 13 anos de iniciação; e Júnior possui 11 anos de iniciação e nascimento. Mesmo fazendo as contas das idades de santo e biológica, Júnior possui um lugar privilegiado na relação da família com os orixás.

Numa perspectiva mais ampla, podemos dizer que uma criança pode possuir efetiva autoridade ritual sobre um adulto. Para tal afirmação utilizo um artifício comparativo. Durante o trabalho de campo, pude perceber que a possessão naquele terreiro pode ser induzida pela pronúncia de certas palavras às quais o orixá está condicionado a "baixar" no cavalo. Presenciei as ialorixás induzirem a possessão em pelo menos três adeptos. Ao perguntar sobre o fato me foi concedida a resposta de que somente autoridades de alto escalão podem realizar tal feito. Se Júnior, 11 anos, tem a mesma autoridade de induzir a possessão de um adepto assim como adultos, como as ialorixás, isso me levou a deduzir que, naquele espaço, Júnior é uma autoridade em alguns níveis e sob determinadas condições. Na entrevista, perguntei a Júnior se algum filho de santo de sua avó já o havia desrespeitado quando das cerimônias e ele me disse que sim, e que, se após ter sido chamado à atenção o filho de santo continuar a desrespeitá-lo, ele chama o orixá daquela pessoa para colocá-la "em seu lugar". Eu nunca presenciei tal situação, mas de acordo com Júnior, Mércia, Regiane e Cristina isso aconteceu pelo menos uma vez, e Júnior agiu "como deveria ter agido". Eu também os questionei se algum dos ogãs havia abusado dessa autoridade em relação aos filhos de santo, e todos disseram que isso nunca aconteceu.

Esses dados me levam a concluir que Júnior experimenta essa autoridade de uma forma natural. Se existiu a convergência de interesses em conceder a Júnior esse lugar, isso não apaga o fato de que sua autoridade é exercida de fato e de direito dentro do terreiro. O lugar de Júnior no terreiro Omin Mafé é garantido como a qualquer ogã, como a qualquer autoridade. É verdade que devemos ponderar as possíveis manipulações rituais em vistas a garantir a participação dos mais jovens, ou de garantir um lugar de autoridade para alguns. Também se deve ponderar a participação assistemática dos mais novos no culto, mas a mim parece que a questão da autoridade ritual perpassa essas variantes e se mostra efetiva, ou, se não for ousar demais, eu diria eficaz. 


\section{“Ogã sem axé não faz orixá virar"}

Dentro da estrutura do candomblé de modelo ketu ${ }^{2}$ existe uma diferenciação básica no que refere à capacidade mediúnica dos adeptos. Existem aqueles que possuem a condição de entrar em transe, de serem possuídos por seus orixás ou por outros espíritos. Diz-se que esses são médiuns rodantes. Esses adeptos assim classificados precisam passar pelos rituais de iniciação a fim de serem realmente considerados membros do candomblé. A iniciação no candomblé é o nascimento para a religião, e é definida como um processo que só tem fim na compleição dos sete anos de iniciação. A partir daí, o filho de santo passa a ser conhecido como ebômim, e recebendo a permissão ritual da mãe ou do pai de santo e dos orixás poderá abrir seu próprio terreiro ou assumir altos cargos na hierarquia do terreiro.

Os não rodantes quando iniciados propriamente são dotados de uma autoridade ritual inscrita em seu odum. A essas autoridades são dados os nomes de ogãs, no caso dos homens; e ekedis, no caso das mulheres. Numa relação direta de comparação, é como se o ogã e a ekedi já nascessem aquilo que os rodantes só serão após sete anos de iniciação no candomblé. Mais adiante explorarei melhor essas noções. Mas o que quero ressaltar é que se um ogã ou uma ekedi nascem tendo como destino serem autoridades, necessitando apenas o ritual de consagração, isso significa que uma criança pode ser uma autoridade no candomblé se ela tem em seu destino a posição de ogã ou ekedi. Mais adiante examinaremos mais amplamente esse aspecto do conceito de ogã que é o que nos interessa nesse momento.

No contexto das tradições de matriz africana, são tomadas por destaque as figuras dos sacerdotes maiores destas que são conhecidos em algumas tradições, como no candomblé ketu, por ialorixás e babalorixás, ou mais popularmente como mães e pais de santo. Aqui será feita referência ao candomblé ketu, enfatizando que vários tipos de religiões enquadradas como de matriz

2 O candomblé como religião de matriz africana fundada no Brasil tem em sua composição elementos de diversas dinâmicas religiosas africanas. Em África, cada nação, tribo ou estado tinha uma dinâmica religiosa diferenciada. No candomblé brasileiro, cada terreiro pertenceria a uma "nação" que tem um cunho de definição de linearidade. Na prática, cada terreiro se baseia nesse sistema classificatório, porém essa classificação é agenciada, no sentido de que é submetida ao "estilo" e ao modo de fazer do dirigente do terreiro. 
afro-brasileira, existindo ainda várias definições regionalmente diferenciadas. Temos ainda a presença de outras autoridades, como: iaegbé, ialaxé, iaquequerê, iatebexé, ajibonã, iamorô, iabassé, que são títulos destinados a adeptos que entram em transe, e que no dia a dia dos terreiros são de suma importância para a manutenção e progresso deste, que seria possível através da renovação contínua do axé. ${ }^{3}$ Uma dessas autoridades é o ogã, figura geralmente masculina que, na constituição do alto clero num terreiro de candomblé, pode se apresentar desempenhando atividades especializadas e que tem lugar como uma autoridade forte na estrutura ritual.

Nas ocorrências na literatura específica de religiões de matriz africana sobre o ogã, encontramos em abundância a informação de que a presença deste no terreiro teria uma dimensão social mais evidente (Braga, 2005; Rodrigues, 2005). Isso significa que o ogã é mais amplamente retratado como um membro do terreiro que cuida das relações públicas, desde receber as pessoas que comparecem a festas a mediar as relações com o externo ao grupo. Muitos intelectuais e artistas receberam a alcunha de "ogãs de sala", título que os reconhecia como membros dos terreiros, e essa ligação traz prestígio para os terreiros, ao passo que serviu como habilitação maior para os intelectuais realizarem suas pesquisas. Autores dos conhecidos como primeiros estudos afro-brasileiros, como Nina Rodrigues, Artur Ramos e Édison Carneiro, receberam tal título em terreiros de candomblé na Bahia (Birman, 1995; Dantas, 1988; Prandi, 1991), e outro aspecto dessa conexão é que durante a forte repressão aos terreiros, mais evidente na década de 1930, esses mesmos intelectuais colaboraram, ao seu modo, para a defesa dos cultos contra a violência policial (Braga, 2005), racismo institucional, bem como com sua contribuição financeira. Essa associação dos ogãs, como figuras agregadoras de prestígio, protetores e patrocinadores,

3 Axé conforma-se como uma categoria êmica que se remete a uma espécie de energia, provinda da relação do povo de santo com o sagrado, energia a qual se relaciona à força (Dantas, 1988) do terreiro. A contínua renovação do axé é feita a partir de rituais internos e públicos, não apenas através dos grandes sacrifícios, mas também na obediência de prescrições e na realização de pequenos afazeres, como na limpeza dos assentamentos, por exemplo. Diz-se que um terreiro possui um "forte axé" geralmente quando é muito frequentado por clientes e o dirigente possui muitos filhos de santo, o que quer dizer que o dirigente realiza atividades rituais de forma "eficaz", e por essa razão torna-se bastante conhecido e dono de prestígio. São muitas as formas de um terreiro ganhar prestígio; ver Bastide (1973), Birman (1995), Dantas (1988) e Lima (2003). 
torna-se então a informação mais disseminada, negligenciando outras abordagens e limitando-se geralmente a descrever suas funções. ${ }^{4}$

A determinação de que uma pessoa seria ogã tem como fonte o jogo de búzios, oráculo de adivinhação manejado pela sacerdotisa ou sacerdote que se constitui um canal direto com os orixás, sendo assim uma ordem vinda do sagrado. Isso geralmente ocorre no primeiro jogo de búzios tirado para o aspirante a adepto, digamos assim. Configura-se o que poderíamos tentar apontar como uma primeira "classificação" das pessoas que frequentam ou se vinculam a um terreiro: rodantes ou não rodantes. Determinado isso, e não obedecendo a uma ordem de respostas a essas informações, além de ter outras informações pessoais respondidas, se assim desejar, o então aspirante fica sabendo quais seriam os orixás "donos da sua cabeça", ${ }^{5}$ e qual o caminho que esses orixás o indicam a seguir; se deve permanecer naquele terreiro, se deve procurar outro, a que orixá o aspirante como ogã pode ou deve servir. ${ }^{6}$ Essa indicação pode ocorrer também em público, quando de uma celebração, o orixá que pretende aquela pessoa como ogã o aponta, quando da possessão, em meio a alguma celebração pública no terreiro (Lima, 2003; Rios, 2004). ${ }^{7}$ Ser ogã seria, antes de tudo, uma espécie de condição, como já dito, geralmente reservada aos homens, daquele que não entra em transe, mas que possui ligação com seus orixás e mediunidade. Essa condição pode ser "confirmada", vinculando o adepto a um terreiro, ou não, se o adepto não aceitar entrar de fato para a religião, o que não o isenta de prováveis "cobranças" dos orixás. ${ }^{8}$

Se a pessoa consente tornar-se um adepto, ou "filho da casa", ocorre, a partir daí, uma série de rituais de "confirmação" de sua posição como ogãa, antes mesmo de ser de fato iniciada. Geralmente, ocorre o rito de "suspensão", que se

4 Para maiores referências sobre as funções do ogã, ver Querino (1955), Braga (2005), Rios (2004).

5 Diz-se que cada pessoa possui três orixás a guiar-lhe: o "orixá de cabeça", que seria o principal, cuja ligação com o adepto é maior; o "orixá adjunto" ou "junto"; e o "orixá de ano" (Luz, 2000; Prandi, 1991).

6 Mais adiante será abordado o serviço do ogã.

7 Tendo o orixá possuído seu cavalo em alguma celebração, ele em algum momento de sua dança vai em direção ao ogã e leva pelo barracão como uma forma de tornar pública sua escolha. Para mais detalhes, ver Rios (2004).

8 Diz-se nos terreiros que aquele que não obedece às vontades de seu orixá sofrerá cobranças, que seriam infelicidades na vida pessoal, como problemas de saúde, financeiros, amorosos ou familiares. 
constitui em um ritual de consagração (Bourdieu, 1974) para aquele que está sendo suspenso; algum tempo depois ocorre o rito da "confirmação", oportunidade em que muitas vezes o adepto recebe um cargo no terreiro (Braga, 2005). Em alguns terreiros chega-se inclusive a iniciar os ogãs à moda da iniciação dos rodantes, com sacrifício de animais, raspagem de parte da cabeça do iniciado, entre outros preceitos. ${ }^{9}$ Vale ressaltar que tal constituição iniciática é variável, sendo a suspensão e a confirmação as mais encontradas na literatura.

Entende-se que aquele apontado como ogã já nasce com prestígio, porém o cargo que o vincula a determinado terreiro só é concedido mediante a sua confirmação. ${ }^{10}$ Segundo Lima (2003, p. 93), "a confirmação do ogã obriga a pessoa distinguida a uma série de ritos propiciatórios até à festa pública da sua apresentação formal, vestido de branco, como todo iniciado, pelo santo que o escolheu". Afirma ainda:

O ogã, desde confirmado, terá vários símbolos expressivos de seu status: terá um nome novo, um nome iniciático, que é gritado no barracão pelo orixá que o "tirou", no dia da confirmação; terá uma cadeira especial, muitas vezes com o nome do ogã gravado na cadeira ou numa placa de metal; receberá as reverências dos filhos da casa que, se forem filhos do mesmo santo que escolheu o ogã, o chamarão de "meu pai". (Lima, 2003, p. 93).

Um ogã pode ser apontado para servir um determinado orixá, geralmente o orixá do sacerdote maior do terreiro, e como aprendiz de "guardião" dos conhecimentos rituais para a alimentação do axé do terreiro, que também toma lugar na relação do sacerdote com seu orixá. Seu prestígio está também nessa salvaguarda, e por isso a ele se deve respeito perante toda a comunidade do terreiro. Lima (2003) afirma que a indicação do ogã pode ser negociada por simpatia ou concessão de privilégios. Sobre o alto clero, Lima (2003, p. 88) afirma que é entre os ogãs confirmados que os dirigentes do terreiro escolhem "'o seu estado maior' masculino", composto pelo axogun, o dono da faca, "mestre dos

9 Para mais detalhes sobre a confirmação de ogãs, ver Braga (2005).

10 Tais informações foram arrecadadas durante a pesquisa sobre a relação da mitologia ioruba e as relações sociais no terreiro Omin Mafé, em Sergipe, e se apresenta em meu trabalho de conclusão do curso de graduação em Comunicação Social pela Universidade Federal de Sergipe. 
sacrifícios" (Rodrigues, 2005); o pejigã, o guardião do peji; e o alabê, o maestro ou regente da orquestra dos atabaques. Ainda acerca do "alto clero", diz Lima (2003, p. 94): "Esses cargos têm fundas implicações ritualísticas e são exercidos por ogãs que 'foram criados no candomblé, geralmente filhos ou sobrinhos de filhas-de-santo da casa, ou de pessoas a intimidade das mães e pais-de-santo." Lima (2003, p. 98) também comenta de ogãs que tocam em terreiros alheios por dinheiro.

Quando um ogã é especulado no Omin Mafé, Mãe Bequinha joga os búzios mais de uma vez a fim de eliminar a margem de erro na interpretação do oráculo. Além disso, durante o bori do ogã, primeira instância de iniciação, a mãe de santo canta mais insistentemente as músicas do orixá daquele ogã além de "bater o adjá" várias vezes em sua cabeça. Mãe Bequinha, dirigente do terreiro, afirma que insiste muito mais com os ogãs e ekedis para que não caia no erro comum de confirmar um ogã ou uma ekedi e depois de alguns anos eles passarem a rodar. Para ela, isso seria motivo de vergonha para o terreiro.

No caso das crianças e adolescentes que são ogãs, quando ainda eram muito pequenos, Bequinha consultou os búzios para saber o orixá e o odum dos netos. Sabendo-se que aquele menino é um ogã, a família já mostra orgulho por isso, construindo uma identidade diferenciada em relação àqueles que são rodantes. Não se teve notícias de brigas entre os netos envolvendo humilhações dos meninos que são ogãs e os que não são. Nunca percebi distinções por parte dos pais ou tios. No caso de Júnior, que é ogã e abiaxé, ele se constitui como uma referência entre os adultos, sendo elogiado por todos da família e por alguns filhos de santo do terreiro. Regiane diz que Júnior é um orgulho pelo fato dele se comportar como uma autoridade, por saber a importância de sua posição, "diferente de filhos de santo mais velhos cronologicamente que não são interessados como ele", diz Regiane, não apenas por seu destino como ogã e abiaxé. "Ele está no lugar dele", diz Cristina, sua mãe.

Ekedis e ogãs são para Mércia e para Júnior, 11 anos e ogã, autoridades essenciais por não rodarem no santo e por poderem rodar qualquer pessoa no santo, ou seja, o ogã e a ekedi possuem a autoridade ritual de invocar os orixás. Já nascem "grandes", e são o braço direito da mãe de santo. Ainda segundo Ana Mércia o rodante e o não rodante se completam, e segundo Regiane, iaquequerê, caso alguma "coisa aconteça" e faça todos virarem no santo, são os ogãs e ekedis que estão presentes para garantir a ordem no culto. Para Martha Sales, ialaxé, 
sem os rodantes não há a perpetuação da religião, mas os não rodantes são personagens imprescindíveis para o culto, posto que suas funções estão diretamente ligadas ao contato com o sagrado. Lima $(2003$, p. 88) cita uma observação de Roger Bastide sobre ogãs e ekedis em que estes seriam "pessoas que não podem cair no santo", "para que a ordem e as normas do ritual sejam normalmente seguidas". A ekedi Mérica enfatiza que rodantes não se dominam, e que os não rodantes ajudam, fiscalizam o processo para que tudo (nos rituais de possessão) saia bem. É importante enfatizar que se os ogãs e as ekedis garantem a ordem quando da possessão, e que crianças podem ser ekedis ou ogãs, isso significa que a ordem também é mantida por crianças.

Entre os ogãs no terreiro, novos e mais velhos, parece existir uma "aura", uma elegância arrogante, como afirma uma filha de santo. Com relação aos ogãs-alabês isso é ainda mais óbvio em meio à função de destaque público em que se posicionam nas grandes festas. Seria um correlato análogo aos grupos musicais nas igrejas católicas e pentecostais. Os integrantes da banda possuem uma posição, um status, evidentemente acima dos membros comuns, que até mesmo sentam em lugares diferenciados. Essa postura é visível também nos ogãs-crianças, mas devo dizer que em casos de ter observado ou percebido um equívoco nos toques dos outros, ou em como se organizou o xirê ou o banquete, já vi várias vezes Júnior, Alisson e Wilber se dirigirem a Mãe Bequinha ou a Paulo César para dizer que determinada coisa está errada.

Mas como Júnior e outras crianças têm acesso ao conhecimento dos fundamentos sagrado?

\section{O conhecimento do sagrado}

A estrutura hierárquica do candomblé de Mãe Bequinha se fundamenta amplamente na vivência e na aquisição de conhecimento pelo cotidiano. As relações de poder se estabelecem geralmente numa ordem decrescente desde aquele que tem mais tempo de iniciação até aquele que se iniciou por último. As crianças no Omin Mafé possuem uma oportunidade de conviver com o candomblé que muitos filhos e filhas de santo não possuem: no dia a dia. Em entrevista, Regiane afirma que vê com bons olhos essa inserção das crianças desde cedo na tradição, pois compara essa inserção com o catecismo católico. O problema, 
para ela, é que as crianças passam a saber demais, e sabem até mais que alguns filhos de santo mais velhos, o que para Regiane é quase uma vergonha, além de que as crianças tornariam públicos alguns segredos quando de suas brincadeiras.

Regiane conta que é comum os sobrinhos e sua filha brincarem de candomblé na escola, e que às vezes eles banalizam procedimentos muito caros à religião. Para Camilo, 12 anos, as brincadeiras de candomblé são uma forma de assumir a tradição de sua família, da qual nem ele nem seus primos parecem ter vergonha. Carol chama de "burros" os colegas que falam mal do candomblé. Regiane fala de filhas e filhos de santo com mais de sete anos de santo que não sabem certos procedimentos que sua filha Carol de 10 anos sabe. Cristina já olha isso com mais orgulho ao dizer que seus filhos e sobrinhos sabem muito mais de tradição do que os filhos de santo de sua mãe, porque as crianças, nas palavras de Cristina, "vivem o candomblé". Dos dois pontos de vista uma coisa parece certa: as crianças sabem mais que alguns adultos no terreiro. O lugar delas no candomblé é de vantagem em relação a algumas filhas e filhos de santo, estes já velhos no santo. O lugar delas é um lugar que as considera detentoras de um saber e esse saber estrutura uma forma de hierarquia entre aqueles que sabem mais e aqueles que sabem menos.

Em Mind, materiality and history, Christina Toren (1999) afirma que através do tempo as crianças constituem o significado e comportamento ritual, e isso é crucial para o processo de saber "o que fazer e como fazer" - isto é, o comportamento apropriadamente ritual - muito antes de poderem conferir a esse comportamento os sentidos que aos adultos parecem óbvios. Adultos estruturam as condições que as crianças encontram no mundo, mas o processo de fazer sentido deste não é determinado pelas pessoas ao redor da criança; a criança tem então que constituir novos sentidos do mundo vivido.

O modelo unificado de ser humano de Toren (1999, p. 12, tradução minha) é dado na seguinte afirmação: “A mente é uma função da pessoa que é constituída com o passar do tempo em relações intersubjetivas com outras pessoas no mundo." A criança está no mundo vivido em relação com muitas pessoas diferentes que trazem consigo suas próprias histórias vividas em qualquer encontro, e relações intersubjetivas são essenciais para o processo de autopoiesis (Maturana; Varela, 1980) em que a criança faz sentido do mundo vivido enquanto o experimenta. Para Toren, humanos são biologicamente seres 
sociais, porque necessariamente se relacionam com outras pessoas, porém essas pessoas não determinam o que nos acontece.

Uma das elaborações teóricas da autora pode ser encontrada em Toren (2011), um modelo que sintetiza contribuições dos neurobiólogos Maturana e Varela $(1980,1988)$ sobre autopoiesis; a ideia de constituição contínua de esquemas cognitivos como "sistemas autorreguladores" de Jean Piaget (1971, p. 113); a fenomenologia de Husserl e Merleau-Ponty e insights vygotskianos sobre aquisição de linguagem. Toren toma como referência a ideia de intencionalidade de Merleau-Ponty, ainda que o termo tenha sido definido por Franz Brentamo. Intencionalidade seria "a conexão com o mundo", posto que é experimentando o mundo que o conhecemos (Merleau-Ponty, 1962). É por experimentar o mundo e reconhecer essa experiência que a projeção da realidade ocorre sobre os objetos no mundo. Christina Toren avança afirmando que a intencionalidade é uma função da intersubjetividade, e é um fenômeno histórico. É vivendo no mundo com pessoas com o passar do tempo que nós constituímos quem somos. Nossas ideias e práticas são produzidas e transformadas no curso do processo histórico que é a nossa cognição. Esse trabalho da antropóloga traz ainda referências de neopiagetianos como Karmiloff-Smith e neoconstrutivistas como Elman e colegas, divergindo desses no que toca a intersubjetividade, que ela entende como analiticamente prioritária. Nessa mesma linha, Toren argumenta sobre um entendimento de que o processo micro-histórico de constituição de ideias com o tempo demanda uma análise social do processo em que $o$ aprendizado toma lugar.

Berliner e Sarró (2007, p. 5, tradução minha) oferecem um insight acerca da compreensão do processo de aprendizado e transmissão de conhecimento religioso: "[...] uma coisa nós não podemos definitivamente fazer é afirmar que seja lá o que [...] chamamos de 'religião' (seja suas convicções subjetivas ou instituições sociais) é algo que vem simplesmente 'sem aviso'. As pessoas vivem em sociedade, e é em sociedade que são socializadas e aprendem a ser adultos adultos religiosos, às vezes". Os autores afirmam que "sem o aprendizado, sem a transmissão, não existe a religião" (Berliner; Sarró, 2007, p. 19, tradução minha). Na mesma organização, no capítulo escrito por Márcio Goldman, o autor argumenta que nas religiões afro-brasileiras a pessoa que ensina se constitui com o passar dos anos, passando por cerimônias de iniciação, e então o equilíbrio da pessoa é alcançado caso todas as prescrições tenham sido cuidadosamente 
observadas. Aquele que aprende está em meio à de construção de sua pessoa, e o "sucesso depende de sua capacidade de acompanhar o processo, o qual não envolve somente o 'conhecimento"' (Goldman, 2007, p. 109, tradução minha), mas principalmente como o caminho foi seguido. Nesse sentido, aprender é a ação que instrumentaliza o "eu" a ser uma pessoa completa.

E se tem algo que as crianças possuem, é uma inegável capacidade para aprender (Hirshfeld, 2002). O conhecimento não significa que as crianças dão ordens expressas e são obedecidas, pois a estrutura familiar de sangue controla isso. Como no caso em que Paulo César pediu a seu filho Júnior para fazer Cristina ser possuída. Cristina, que é mãe de Júnior e esposa de Paulo César, me contou que um dia chegou do trabalho e só queria tomar um banho e assistir à novela das oito. Ela diz que depois do banho foi à cozinha comer algo e viu uma caixa de chocolates e alguns iogurtes, tipo de comida que os erês adoram. Nesse momento ela entendeu o plano de Paulo César; ele comprou tudo aquilo para à noite pedir que seu filho Júnior pudesse "chamar" o orixá ou o erê da mãe. Paulo César precisava de alguns conselhos das entidades para problemas pessoais, e assim podia consultá-las através da autoridade ritual de Júnior, que é ogã suspenso do terreiro da mãe. Os erês costumam pedir alguns agrados como doces e chocolates quando são chamados nessas situações.

Júnior exerce uma autoridade ritual perante sua mãe biológica, mas a pedido de seu pai. Ele possui a autoridade de fato e de direito, pois ele é ogã e abiaxé, mas sob a responsabilidade do pai. O pai legitima de certa forma a performance de autoridade de Júnior. E essa não foi uma oportunidade única que indicou minha interpretação. Tenho dados etnográficos suficientes que confirmam a legitimidade da autoridade dos ogãs-crianças, embora geralmente sob a tutela de adultos. Essa autoridade é assumida com naturalidade e, embora não seja motivo de várias conversas, por exemplo, é uma experiência pública dentro do âmbito do terreiro, não um acordo da família de sangue apenas. Existem casos de filhos de santo do terreiro sem laços de consanguinidade que estiveram em conflito com um dos netos da ialorixá que são ogãs. Na maioria dos casos, o ogã não se intimidou e fez o filho de santo ser possuído. Quando um filho de santo não se comporta conforme o respeito aos princípios básicos do candomblé, é função dos membros da hierarquia chamar o orixá daquele que infringiu as regras para que o orixá "dê conta e resolva o problema do filho de santo". 


\section{O self sagrado do ogã-criança}

A tradição das abordagens fenomenológicas sobre a religião tem inspiração no francês Maurice Merleau-Ponty, que argumenta contra a ideia descartiana de uma dicotomia entre corpo e mente. Para Merleau-Ponty (1962), o corpo compõe um sistema com o "objeto".

Se a "mente é função de toda a pessoa constituída ao longo do tempo em relações intersubjetivas com os demais no mundo circundante" (Toren, 1999, p. 12, tradução minha), no candomblé a intersubjetividade deve ocorrer nas relações com os orixás. Assim, em qualquer ponto do candomblé, a natureza da intersubjetividade está mudando em função do que está acontecendo. Por exemplo, quando a mulher que costumo chamar de madrinha se comporta de determinada maneira, não a chamo de madrinha porque sei que ela não responderá. A "pessoa inteira' se manifesta de maneiras diferentes de acordo com as relações que estão envolvidas.

Existe a disposição definida pelo odum, negociada em termos pelo orixá, e legitimada publicamente pelos membros da hierarquia. Prestando atenção em como performam os ogãs - entre eles estão o pai de Alisson e Júnior e tio de Wilber, Paulo César - os meninos prestam atenção num modelo de estar no candomblé. Existe a necessidade de conhecer os fundamentos do candomblé, de respeitá-los, aceitá-los em sua vida, assumir as responsabilidades da autoridade a si destinada, segundo Mércia, e de incorporar uma gramática de gestos que identificam aquele ogã em meio à comunidade religiosa. É através da experiência perceptiva que os ogãs-crianças compreendem o seu estar no mundo e são esses esquemas conceituais que permitem que as crianças percebam $o$ mundo natural e social como um todo orgânico. A verdade vivida é naturalizada. Em suma, a autoridade ritual dos ogãs-crianças parece contribuir para o projeto de reformulação dos limites entre o que é natural e o que é sobrenatural, entre o que é socialmente "estabelecido" e o que possibilita o ritual. 


\section{Referências}

BASTIDE, R. Estudos afro-brasileiros. São Paulo: Perspectiva, 1973.

BERLINER, D.; SARRÓ, R. (ed.). Learning religion: anthropological approaches. New York: Berghahn Books, 2007.

BIRMAN, P. Fazer estilo, criando gêneros: estudo sobre a construção religiosa da possessão e da diferença de gêneros em terreiros de umbanda e candomblé no Rio de Janeiro. Rio de Janeiro: Relume Dumará: EdUerj, 1995.

BOURDIEU, P. A economia das trocas simbólicas. São Paulo: Perspectiva, 1974.

BRAGA, J. A cadeira do ogã e outros ensaios. Rio de Janeiro: Pallas, 2005.

DANTAS, B. G. Vovó nagô, papai branco: usos e abusos da África no Brasil. Rio de Janeiro: Graal, 1988.

FALCÃO, C. R. Ele já nasceu feito! O lugar da criança no Candomblé. 2010. Dissertação (Mestrado em Antropologia Social) - Centro de Filosofia e Ciências Humanas, Universidade Federal de Pernambuco, Recife, 2010.

GOLDMAN, M. A possessão e a construção ritual da pessoa no Candomblé. 1984. Dissertação (Mestrado em Antropologia Social) - Museu Nacional, Universidade Federal do Rio de Janeiro, Rio de Janeiro, 1984.

GOLDMAN, M. A construção ritual da pessoa: a possessão no Candomblé. Religião e Sociedade, Rio de Janeiro, v. 12, n. 1, p. 22-54, ago. 1985.

GOLDMAN, M. How to learn in an Afro-brazilian spirit possession religion: ontology and multiplicity in Candomblé. In: BERLINER, D.; SARRÓ, R. (ed.). Learning religion: anthropological approaches. New York: Berghahn Books, 2007. p. 103-119.

GUEDES, M. [Stela Guedes Caputo]. Educação em terreiros e como a escola se relaciona com crianças que praticam candomblé. 2005. Tese (Doutorado em Educação) - Pontifícia Universidade Católica do Rio de Janeiro, Rio de Janeiro, 2005.

HIRSCHFELD, L. A. Why don't anthropologists like children. American Anthropologist, [s. l.], v. 104, n. 2, p. 611-627, 2002.

LIMA, V. C. A família-de-santo nos candomblés jejes-nagôs da Bahia: um estudo de relações intragrupais. Salvador: Corrupio, 2003.

LUZ, M. A. Agadá: dinâmica da civilização africano-brasileira. Salvador: Edufba, 2000. 
MATURANA, H. P.; VARELA F. J. Autopoiesis and cognition: the realisation of the living. Dordrecht: D. Reidel, 1980.

MATURANA, H. P.; VARELA F. J. The tree of knowledge. Boston: New Science Library, 1988.

MERLEAU-PONTY, M. Phenomenology of perception. London: Routledge, 1962.

PIAGET, J. Structuralism. London: Routledge \& Kegan Paul, 1971.

PRANDI, R. Herdeiras do axé: sociologia das religiões afro-brasileiras. São Paulo, Hucitec, 1996.

PRANDI, R. Os candomblés de São Paulo: a velha magia na metrópole nova. São Paulo: Hucitec: Edusp, 1991.

QUERINO, M. A raça africana e seus costumes. Salvador: Livraria Progresso, 1955.

RABELO, M. A possessão como prática: esboço de uma reflexão fenomenológica. Mana, Rio de Janeiro, v. 14, n. 1, p. 87-118, 2008.

RIOS, L. F. O feitiço de Exu: um estudo comparativo sobre parcerias e práticas homossexuais entre homens jovens candomblesistas e/ou integrantes da comunidade entendida do Rio de Janeiro. 2004. Tese (Doutorado em Saúde Coletiva) - Instituto de Medicina Social, Universidade do Estado do Rio de Janeiro, Rio de Janeiro, 2004.

RODRIGUES, N. Animismo fetichista dos negros baianos. Salvador: P55 Edição, 2005. (Coleção Auto-conhecimento Brasil).

SEGATO, R. L. Santos e daimones: o politeísmo afro-brasileiro e a tradição arquetipal. 2. ed. Brasília: Editora da Universidade de Brasília, 2005.

TOREN, C. Mind, materiality and history: explorations in Fijian ethnography. London: Routledge, 1999.

TOREN, C. The stuff of imagination: what we can learn from Fijian children's ideas about their lives as adults. Social Analysis, [s. l.], v. 55, n. 1, p. 23-47, Spring 2011.

Recebido: 31/01/2020 Aceito: 29/03/2021 | Received:1/31/2020 Accepted:3/29/2021 